Acta Theriologica 39 (4): 411-416, 1994.

PL ISSN 0001-7051

\title{
Status and diet of wolves in Greece
}

\author{
Nicolaos PAPAGEORGIOU, Christos VLACHOS, \\ Athanasios SFOUGARIS and Efstathios TSACHALIDIS
}

\begin{abstract}
Papageorgiou N., Vlachos C., Sfougaris A. and Tsachalidis E. 1994. Status and diet of wolves in Greece. Acta theriol. 39: 411-416.

The stomach contents of 32 wolves Canis lupus Linnaeus, 1758 collected throughout Greece during autumn and winter 1991 and 1992 were examined for prey remains. Of these 28 stomachs contained measurable quantities of food. Of the 19 species that were found in the wolf diet 12 species were mammals. The main food items were goats, sheep, pigs and cows. Large wild herbivores did not play a significant role in the wolf diet. The observed consumption of grasses and fruits are important when they are available. The maximum food content in the examined stomachs was $1860 \mathrm{~g}$.

Department of Forestry and Natural Environment, Laboratory of Wildlife and Freshwater Fisheries, Aristotelian University, 54006 Thessaloniki, Greece
\end{abstract}

Key words: Canis lupus, food, predation, Greece

\section{Introduction}

The wolf Canis lupus Linnaeus, 1758 populations in Europe during the past $300-400$ years have been declining drastically and the species has been extinct in most of its historical range with the exception of the Russian population which in recent years has shown a positive trend, with the expansion of the range and an increase in the number of individuals (Pimlott 1976, Genov 1987, Okarma 1989).

Wolves have been and will continue to be the subject of considerable controversy. The popular belief which prevailed in many European countries that wolf predation has contributed to the decline of many species of large wild herbivores and is responsible for many damages to domestic animals were the main reasons for the wolf's decline. Many European countries initiated wolf control programs in an effor to reduce its numbers. The present situation is that breeding populations of wolves still occur in Russia, Poland, Czech Republic, Slovakia, Romania, Bulgaria, Albania, Greece, Italy, Portugal and Spain (Pimlott 1976).

The observed cases of damage done by wolves to livestock and large wild herbivores was the reason for the development of social attitudes towards them. There are, however, far too little scientific data on the impact of the wolf on ungulate populations. Fundamental research has been initiated to obtain a better undestanding of the functional role that wolf plays in ecosystems (Jędrzejewski et al. 1992, Okarma 1993). 
Information on the food habits of the wolf is needed to ensure that the species is managed wisely. The wolf has been investigated in many European countries (Thompson 1952, Voight et al. 1976, Fritts and Mech 1981, Reig et al. 1985, Salvador and Abad 1987, Okarma 1989, 1993, Cuesta et al. 1991, Meriggi et al. 1991). However, data on the various food items consumed by wolves in Greece are not available regarding the nature of various food items consumed, a point particularly important to assess the effects of wolves on large wild herbivores and livestock.

The objectives of the present study, which was conducted from 1991 and 1992, were to obtain information on the wolf diet and determine the extent of its predation on livestock.

\section{Material and methods}

The 32 wolf stomachs examined, were supplied voluntarily by hunters and by local game wardens. A variety of methods, including organized drives and night shooting, were used to obtain the specimens.

The stomach of each wolf was stored in a $10 \%$ formalin solution. Date, time, area of capture, and size of the animal were also recorded. The contents of each stomach were washed with hot water through a $12 \mathrm{~mm}$ mesh screen sieve to remove grease and later with cold tap water under heavy pressure. Identification of the food items was made with identified reference samples, pictorial references, skin and skeleton materials.

Inspection of guard hair structure was used to identify mammalian remains (Mathiak 1938, Mayer 1952, Stains 1958). Bird remains were difficult to identify except in those cases where a substantial part of their plumage was present in the stomach. Feathers were identified to order by examing the morphology of the nodes of their barbules (Day 1966). Unknown items found in the first samples were numbered until better and identifible specimens were found.

The information from the stomach analyses were used to determine the frequency of occurrence of different food items. Percentage of occurrences were calculated from the ratio between the number of times a particular food item was found in the stomachs to the total number of stomachs examined.

\section{Results}

\section{Status of wolves in Greece}

Wolves in Greece are widely distributed in the central and north part of the country. The species has been accorded total protection in Greece since 1980, when the bounty system was postponed. However, in areas where extensive damage by wolves to domestic animals is observed the local authority can initiate temporary wolf population control by shooting, under the supervision of the Forest Service. The government compensates the owners of domestic animals in full for losses made by wolves.

Data on wolf numbers in Greece are not available. The only data we have are those of wolves killed by hunters and livestock owners and then submitted for bounty to the Forest Service (Table 1). 
Table 1. Location of wolves killed in Greece (1974-1979).

\begin{tabular}{|c|c|c|c|c|c|c|}
\hline Prefecture & 1974 & 1975 & 1976 & 1977 & 1978 & 1979 \\
\hline Attiki & & & & & 1 & \\
\hline Evtritania & & & & 1 & & \\
\hline Viotia & 1 & & & & & \\
\hline Aetoloakarnania & 11 & 7 & 16 & & 10 & 1 \\
\hline Fokida & & 1 & 1 & & & \\
\hline Fhiotida & 3 & 2 & 11 & 10 & 8 & 4 \\
\hline Jannina & 47 & 39 & 28 & 53 & 41 & 33 \\
\hline Thesprotia & 34 & 15 & 6 & 11 & 9 & 18 \\
\hline Preveza & 2 & 2 & 1 & 3 & 7 & 1 \\
\hline Larisa & 23 & 30 & 24 & 31 & 32 & 42 \\
\hline Karditsa & 1 & 2 & 6 & 1 & 8 & 1 \\
\hline Magnisia & 5 & 3 & 6 & 9 & 4 & 2 \\
\hline Achaia & & & & 1 & & \\
\hline Kavala & 59 & 24 & 29 & 23 & 76 & 26 \\
\hline Serres & 160 & 131 & 178 & 71 & 50 & 88 \\
\hline Kilkis & 23 & 20 & 16 & 21 & 31 & 24 \\
\hline Thessaloniki & 58 & 37 & 47 & 46 & 48 & 42 \\
\hline Drama & 72 & 54 & 61 & 72 & 60 & 85 \\
\hline Halkidiki & 33 & 36 & 40 & 42 & 42 & 41 \\
\hline Pela & 38 & 33 & 16 & 30 & 29 & 19 \\
\hline Kozani & 41 & 14 & 85 & 70 & 73 & 60 \\
\hline Pieria & 12 & 9 & 20 & 16 & 13 & 24 \\
\hline Florina & 27 & 32 & 16 & 16 & 4 & 14 \\
\hline Kastoria & 13 & 8 & 2 & 9 & 8 & 15 \\
\hline Grevena & 5 & 9 & 11 & 37 & 44 & 64 \\
\hline Imathia & 17 & 18 & 27 & 16 & 10 & 21 \\
\hline Evros & 38 & 114 & 80 & 101 & 84 & 38 \\
\hline Xanthi & 12 & 6 & 17 & 22 & 16 & 26 \\
\hline Rodopi & 20 & 31 & 19 & 70 & 41 & 24 \\
\hline Total & 755 & 677 & 763 & 782 & 749 & 713 \\
\hline
\end{tabular}

The data show that from 1974 to 1979 on the average 740 wolves were killed annually. Approximately $85 \%$ of the wolves were killed in the northern part of the country.

\section{Diet}

Thirty two stomachs were collected thoughout Greece over the 2-year period of study. Nine stomachs $(28.1 \%)$ were collected in autumn and $23(71.9 \%)$ in winter. From the 32 examined stomachs 28 (88\%) contained measurable amounts of food and $4(12 \%)$ were completely empty or contained only traces of food. The maximum food content in the examined stomachs was $1860 \mathrm{~g}$. 
Of the 19 species which were found in the wolf diet 12 species were mammals. Remains of goats, sheep, pigs, cows, and mice comprised the most common species found in the wolf diet. Remains of goats and sheep were found in $25.0 \%$ and $14.3 \%$ in the examined stomachs. Chicken proved to be the principle avian food identified. Game animals did not play a significant role in wolf diet since only one stomach contained remains of roe deer and one wild boar.

Plant material was found to supplement the wolf diet. Grasses were found in $14 \%$ of the examined stomachs in minute quantities. Pears, plums, figs and fagus seeds were present in $14 \%, 7 \%$ and $7 \%$ respectively at the examined stomachs, by frequency of occurrence.

\section{Discussion}

Data on food habits of the wolves emphasized the importance of large herbivores in the wolf diet and that their availability effects the tendency of wolves to prey on alternate species such as livestock (Cuesta et al. 1991, Merrigi et al. 1991). Our findings showed that wolves in Greece feed to a large extend upon domestic animals and that wild animals do not play a considerable part in their diet.

The low population abundance and distribution of large wild herbivores (red deer, roe deer, chamois) in Greece can explain their small contribution to the wolf diet. The lack of wild herbivores as a natural food source has forced the wolves to change their feeding behaviour and focus upon prey easy to capture and more available such as livestock. Livestock seems to be the main food source of wolves and as a result the wolf is a serious cause of damage and loss to livestock owners. According to the Forest Service data the goverment compansated in full for damages made wolves from April 1989 to June 1991, for 2729 cows and 21000 sheep and goats.
Table 2. Food items found in 28 wolf stomachs collected during autumn and winter.

\begin{tabular}{cc}
\hline Food item & $\begin{array}{c}\text { Frequency } \\
\text { of occurrence }\end{array}$ \\
$(\%)$
\end{tabular}

Mammals

a. Livestock

Goat

25.0

Sheep

Cow

10.7

3.6

b. Wild mammals

$\begin{array}{lr}\text { Mouse } & 10.7 \\ \text { Badger } & 7.1 \\ \text { Pine marten } & 7.1 \\ \text { Stoat } & 3.6 \\ \text { Weasel } & 3.6 \\ \text { Wild boar } & 3.6 \\ \text { Roe deer } & 3.6\end{array}$

Birds

Domestic chicken

Plant material

Grasses

7.1

7.1

7.1

3.6

3.6 
The presence of chicken remains in 5 stomachs reveals their importance to the wolf diet and the tendency of wolves to approach human settlements in search of food. Rodents represent a significant addition to the diet (10.7\%) what should be beneficial to humans.

Grass was ingested in minute quantities. This can be explained that with this food wolves satisfy part of their vitamin C requirements. However, the grasses found in the examined stomachs may have been taken indirectly through other prey species (herbivores). Fruits were found to play a considerable part of the wolf diet. Fruits, when they are abundant, provide an easily obtainable source of carbohydrates for wolves.

The data showed that wolves prey mainly on livestock. The dietary habits of the wolves found in the present study reveals that wolves in order to obtain food extended their range from the forested remote areas towards human's settlements where livestock damages are often observed.

\section{Management implications}

The first priorities for the management of wolves in Greece are:

1. to increase public awareness through educational programs about the role the wolf plays in ecosystem,

2. restore the large herbivore populations to the wolves natural habitat so that predation on livestock can be decreased,

3. the compensation in full for any damages by wolves to livestock owners should be continued by the goverment,

4. promote further research on wolves numbers and distribution.

Study of the food habits of the wolves should be extended for all seasons throughout the country.

\section{References}

Cuesta L., Barcena F., Palacios F. and Reig S. 1991. The trophic ecology of the iberian wolf (Canis lupus signatus Cabrea, 1907). A new analysis of stomach's data. Mammalia 55: 239-254.

Day M. G. 1966. Identification of hair and feather remains in the gut and faeces of stoat and weasels. J. Zool., Lond. 148: 201-207.

Fritts S. H. and Mech L. D. 1981. Dynamics, movements and feeding ecology of a newly protected wolf population in northwestern Minnesota. Wildl. Monogr. 80: 1-79.

Genov D. 1987. The wolf (Canis lupus) in southwest Bulgaria. [In: Abstracts of the XVIII IUGB Congr. B. Bobek, K. Perzanowski, W. L. Regelin and R. Tertil, eds]. Jagiellonian University, Kraków: 66.

Jędrzejewski W., Jędrzejewska B., Okarma H. and Ruprecht A. 1992. Wolf predation and snow cover as mortality factors in the ungulate community of the Białowieża National Park, Poland. Oecologia 90: 27-36.

Mathiak H. 1938. A key to hairs of the mammals of Southern Michigan. J. Wildl. Manag. 2: 251-268.

Mayer W. V. 1952. The hair of California mammals with keys to the dorsal guard hair of California mammals. Am. Mild. Naturalist 48: 480-512. 
Meriggi A., Rosa P., Brangi A. and Matteucci C. 1991. Habitat use and diet of the wolf in nortıern Italy. Acta theriol. 36: 141-151.

Okarma H. 1989. Distribution and numbers of wolves in Poland. Acta theriol. 34: 479-503.

Okarma H. 1993. Status and management of the wolf in Poland. Biol. Conser. 66: 153-158.

Pimlott H. D. 1976. The wolf in Europe in 1973. I.O.C.N. Supplementary Paper No 43: $17-27$.

Reig S., Cuesta L. and Palacios F. 1985. Impact of human activity on the foof habits of the red fox and the wolf in Old Castile (Spain). Rer. Ecol. (Terre et Vie) 40: 151-155.

Salvador A. and Abad P. L. 1987. Food habits of wolf population (Canis lupus) in Leon Provnce, Spain. Mammalia 51: 45-52.

Stains H. J. 1958. Field guide to guard hairs of Middle-Western furbearers. J. Wild. Manage 22: 95-97.

Thomson D. Q. 1952. Travel, range and food habits of timber wolves in Wisconsin. J. Mammal 33: 429-442.

Voigt D. T., Kolenosky G. B. and Pimlott D. H. 1976. Changes in summer food habits of wolves in Central Ontario. J. Wildl. Manage. 40: 663-669.

Received 26 June 1994, accepted 25 October 1994. 